\title{
Standardisation of a simple method for the determination of antithrombin activity
}

\author{
ALBERTO FRIGOLA
}

From the Laboratory of Clinical Pathology, B. Eustachio Hospital, 62027 San Severino Marche, Italy

SUMMARY A procedure is described for performing a functional assay of serum antithrombin activity. The method consists of adding serum to a thrombin solution and measuring, after a fixed incubation time, the residual thrombin activity on a substrate plasma. The mean serum antithrombin activity found in 96 healthy blood donors using this procedure was $109.5 \%$ (range $82 \%$ $160 \%$ ). The method was linear over an activity range between $30.5 \%$ and $176 \%$, was significantly correlated with antithrombin-III protein concentration determined by radial immunodiffusion ( $r=0.86, \mathrm{P}<0.01$ ), and showed good reproducibility (coefficient of variation $2.7 \%$ ). On account of its simplicity and precision this functional assay should be of considerable use in evaluating hypercoagulability.

Over the years the attention of pathologists has been directed almost exclusively to the bleeding disorders of blood coagulation, and every effort has been made to develop laboratory tests designed for the diagnosis of clotting factor deficiencies. Recently, however, it has become evident that the concentration of clot-promoting substances is as important as the concentration of their natural inhibitors (Biggs and Denson, 1976).

Antithrombin-III is perhaps the principal natural inhibitor of thrombin and factor Xa (Yin et al., 1971), and plays a central role in the prevention of intravascular clotting, as demonstrated by the correlation between a reduction of antithrombin activity and thromboembolic phenomena (Egeberg, 1965; von Kaulla and von Kaulla, 1967).

Several functional assays of antithrombin activity have been developed. The procedure described in this paper is a modification of a previous method (Innerfield et al., 1976). This assay shows good precision and reproducibility in measuring serum antithrombin activity and, because it is simple to perform, should be useful as a routine test in evaluating hypercoagulability.

\section{Material and methods}

The population under study consisted of 96 healthy adults (age 24-55; 52 men, and 44 women not taking oral contraceptives) selected by random numbers

Received for publication 31 January 1977 from a list of blood donors. All the subjects had consented to the use of their blood for in vitro studies.

Blood was collected by clean venepuncture with a plastic syringe after minimal venous stasis. Serum was obtained by allowing whole blood to clot into polystyrene tubes at $37^{\circ} \mathrm{C}$ for two hours and then by centrifuging at $2000 \mathrm{rpm}$ for 15 minutes. Serum was used immediately or stored at $-20^{\circ} \mathrm{C}$.

Thrombin solution was obtained by reconstituting Fibrindex (Ortho Diagnostics, 50 U/vial Lot. $10 \mathrm{~N} 215$ ) with $1 \mathrm{ml}$ of isotonic saline according to the manufacturer's instructions. Before the assay, a thrombin working solution $(4 \mathrm{U} / \mathrm{ml})$ was prepared by dilution with isotonic saline.

Ortho Plasma Coagulation Control (Ortho Diagnostics, Lot. 2P81; fibrinogen value $262 \mathrm{mg} / \mathrm{dl} \pm$ $15 \mathrm{mg} / \mathrm{dl}$ ), reconstituted by adding $1 \mathrm{ml}$ of distilled water, was employed as substrate plasma.

Clotting times were recorded by a photo-optical clot detection instrument (Digiclot Elvi 818) provided with a dry heating block set at $37 \cdot 0 \pm 0.5^{\circ} \mathrm{C}$.

\section{ASSAY P ROCEDURE}

Basically the method consists of adding serum to the working thrombin solution and measuring, after a fixed incubation time, the residual thrombin activity. $0.05 \mathrm{ml}$ of serum is added to $0.45 \mathrm{ml}$ of the working thrombin solution, the vial is placed in the heating block, and an interval timer is started. After exactly 3 minutes $0.1 \mathrm{ml}$ of the serum-thrombin mixture is 881 
delivered into $0.2 \mathrm{ml}$ of substrate plasma previously incubated at $37^{\circ} \mathrm{C}$ for 3-5 minutes. Simultaneously, the timer of the clotting instrument will start and the clot formation will be recorded automatically. By the same procedure the clotting time of the working thrombin solution is obtained, but serum is substituted by a solution containing $5 \% \mathrm{w} / \mathrm{v}$ Bovine Serum Albumin (Behringwerke) in Tris-saline solution ( $0 \cdot 154 \mathrm{M} \mathrm{NaCl}, 0 \cdot 2 \mathrm{M}$ Tris-buffer $\mathrm{pH}=7 \cdot 4)$. For all the determinations the test procedure is carried out in duplicate.

The antithrombin activity is expressed by the $\log$ of the ratio between the clotting time obtained after serum incubation $\left(t_{x}\right)$ and the clotting time of the working thrombin solution $\left(t_{c}\right)$.

\section{PREPARATION OF CALIBRATION CURVE}

Pooled serum from 17 healthy donors (assumed to have a $100 \%$ antithrombin activity) is serially diluted with Tris-saline solution to obtain 80,70 , $60,50,35,25$, and $10 \%$ final activity of the test material. A calibration curve is then constructed by plotting the $\log$ of the ratio $t_{x} / t_{c}$ against the percentage of antithrombin activity; the relation obtained (Fig. 1) is a straight line which passes through the origin since the antithrombin activity is zero when $t_{x}=t_{c}$.

\section{ADDITIONAL STUDIES}

Antithrombin-III protein concentration was determined by the radial immunodiffusion method using M-Partigen plates (Behringwerke, Batch no. 0803). The determination of fibrin degradation products was performed by the FDP Test kit (Behringwerke, Batch no. 187).

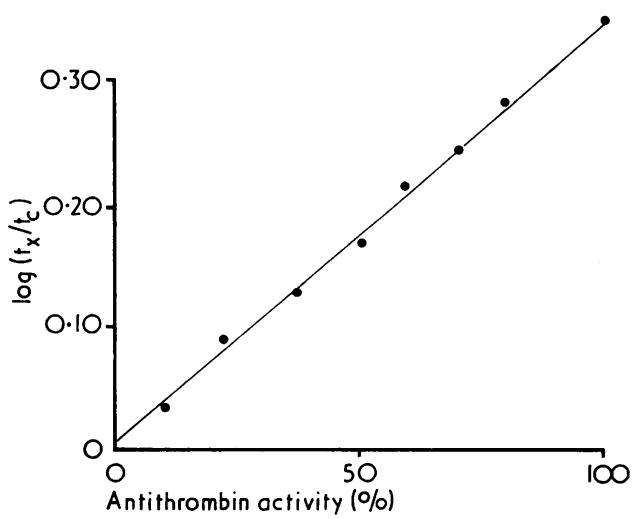

Fig. 1 Calibration curve obtained by plotting the percentage of antithrombin activity against the log $\left(t_{x} / t_{c}\right)$; the equation of the regression line is $y=0.005+0.00345 x$.

\section{Results}

The mean values of serum antithrombin activity $\overrightarrow{\vec{B}}$ found in 96 healthy blood donors are presented in Table 1 . The activity range was $82-160 \%(0 \cdot 29-0.56$ 등 on $\log$ scale) with a mean of $109.5 \%$ and a standard $\overline{\bar{c}}$ deviation of $16 \cdot 3 \%$. Both sexes showed comparable $\overparen{\otimes}$ levels of activity and all the subjects examined were $\stackrel{\varrho}{q}$ negative for the presence of fibrin degradation ${ }^{\infty}$ products.

The precision of the assay was evaluated by $\overrightarrow{\vec{A}}$ performing 28 replicate determinations on a single $\tilde{\sigma}$ serum pool. Coefficients of variation of $2.8 \%$ and $\bar{\Omega}$ $2.7 \%$ were obtained respectively for $\log \left(t_{x} / t_{c}\right)$ and percent of antithrombin activity (Table 2 ).

There was a significant positive correlation $(r=6$ $0.86, \mathrm{P}<0.01$ ) between serum antithrombin activity $\stackrel{\infty}{\infty}$ and antithrombin-III protein concentration. The $\vec{\circ}$ scatter diagram and the resulting regression line are shown in Figure 2.

The method linearity was assessed by measuring $\mathbb{D}$ antithrombin activity on a serum pool after different $\mathbb{\Phi}$ times of incubation. Antithrombin activity increased $\frac{3}{\sigma}$ consistently and progressively as the incubation time $\mathbb{\mathbb { Q }}$ was increased from 1 to 5 minutes. The relation $\overrightarrow{0}$ obtained was a straight line $(y=-5 \cdot 8+36 \cdot 1$ \& $) \searrow$ covering an activity range between $30.5 \%$ and 176 (Fig. 3).

\section{Discussion}

In recent years several methods have been de- $\mathcal{\perp}$ veloped to perform a functional assay of anti- $\overrightarrow{\hat{O}}$ thrombin activity in plasma. The preferential use of 3 plasma has been suggested by the consideration that

Table 1 Mean values of serum antithrombin activity $(n=96)^{*}$

\begin{tabular}{llc}
\hline & $\log \left(t_{x} / t_{c}\right)$ & Antithrombin activity \% \\
\hline Mean & 0.38 & 109.5 \\
Standard deviation & 0.057 & 16.3 \\
Standard error of the & 0.005 & 1.5 \\
$\quad$ mean & 0.05 & \\
\hline
\end{tabular}

*Assuming from the calibration curve $0.35=100 \%$ of activity

Table 2 Precision evaluation of serum antithrombin assay

\begin{tabular}{lcclc}
\hline & $t_{x}^{*}$ & $t_{c}{ }^{*}$ & $\log \left(t_{x} / t_{c}\right)$ & $\begin{array}{l}\text { Antithrombin } \\
\text { activity } \%\end{array}$ \\
\hline Mean & 33.8 & 14.9 & 0.35 & 100.0 \\
$\begin{array}{l}\text { Standard deviation } \\
\text { Coefficient of } \\
\text { variation }\end{array}$ & 1.05 & 0.6 & 0.01 & 2.7 \\
\hline
\end{tabular}

*Time in seconds 


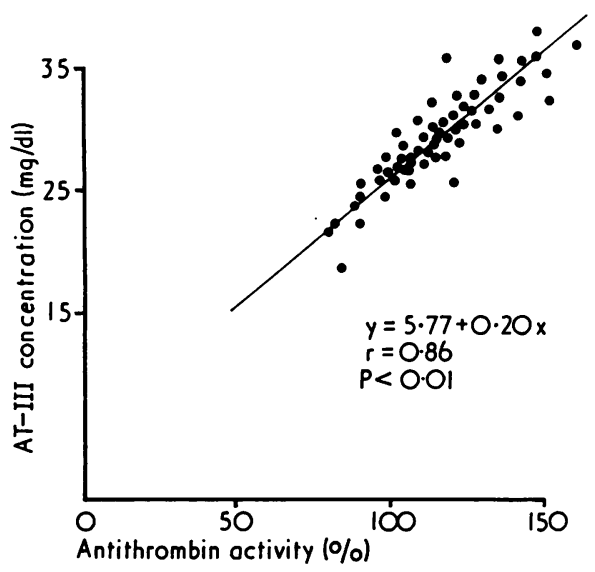

Fig. 2 Correlation between serum antithrombin activity and antithrombin-III protein concentration determined by radial immunodiffusion $(n=58)$.

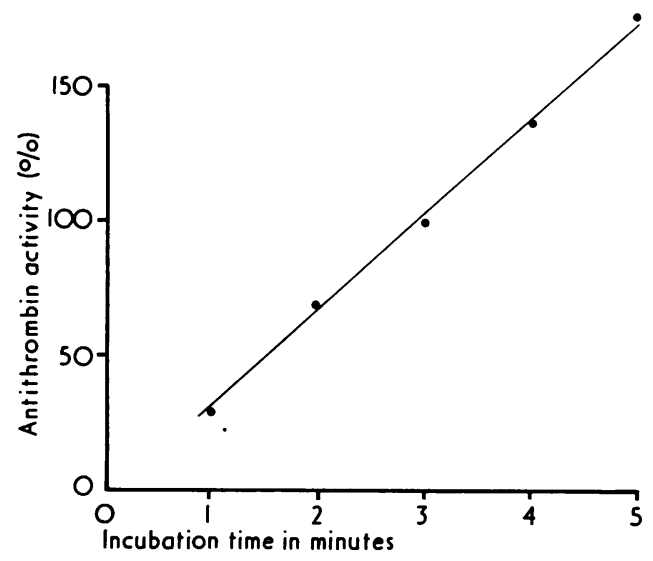

Fig. 3 Effect of incubation time on serum antithrombin activity.

there is a consumption of antithrombin by the thrombin generated during coagulation in vitro, antithrombin activity in serum being about $30 \%$ less than in plasma (Abildgaard et al., 1970). However, there are several drawbacks to the use of defibrinated plasma as a test material. The most obvious disadvantage is the major complexity in the test performance. Furthermore, the defibrination step introduces new and often unchecked variables in the assay system.
The procedure described in this paper uses serum instead of plasma. The results obtained show that the method is linear over a very large activity range, is satisfactorily precise, and is significantly correlated with antithrombin-III protein concentration. The mean antithrombin activity levels reported are comparable with those obtained by using Ancrod defibrinated plasma (Bick et al., 1976) and also with those determined by amidolytic methods (Ødegård and Teien, 1976).

This antithrombin assay requires only a small serum sample, is relatively inexpensive, and has the unique advantages of technical simplicity and speed; it is thus a suitable procedure for the quantitation of antithrombin activity and should be of considerable use as a routine test in evaluating hypercoagulability.

I wish to thank the AVIS, section of San Severino Marche, for effective cooperation, and Mr Sandro Angeloni for photographic assistance.

\section{References}

Abildgaard, U., Fagerhol, M. K., and Egeberg, $O$. (1970). Comparison of progressive antithrombin activity and the concentrations of three thrombin inhibitors in human plasma. Scandinavian Journal of Clinical Laboratory Investigation, 26, 349-354.

Bick, R. L., Kovacs, I., and Fekete, L. F. (1976). A new two-stage functional assay for antithrombin-III (heparin cofactor): clinical and laboratory evaluation. Thrombosis Research, 8, 745-756.

Biggs, R., and Denson, K. W. E. (1976). Natural and pathological inhibitors of blood coagulation. In Human Blood Coagulation, Haemostasis and Thrombosis, edited by R. Biggs, pp. 143-167. Blackwell Scientific Publications, Oxford.

Egeberg, O. (1965). Inherited antithrombin deficiency causing thrombophilia. Thrombosis et Diathesis Haemorrhagica, 13, 516-530.

Innerfield, I., Goldfischer, J. D., Reicher-Reiss, H., and Greenberg, J. (1976). Serum antithrombin in coronaryartery disease. American Journal of Clinical Pathology, 65, 64-68.

Ødegård, O. R., and Teien, A. N. (1976). AntithrombinIII, heparin cofactor and antifactor $\mathrm{Xa}$ in a clinical material. Thrombosis Research, 8, 173-178.

von Kaulla, E., and von Kaulla, K. N. (1967). Antithrombin-III and diseases. American Journal of Clinical Pathology, 48, 69-80.

Yin, E. T., Wessler, S., and Stoll, P. J. (1971). Identity of plasma activated factor $\mathbf{X}$ inhibitor with Antithrombin III and Heparin Cofactor. Journal of Biological Chemistry, 246, 3712-3719. 